\title{
Comparison of Effect of Vacuum-Condensed and Ultrafiltered Milk on Cheddar Cheese*
}

\author{
M. R. Acharya† and V. V. Mistry \\ MN-SD Dairy Foods Research Center, Dairy Science Department, \\ South Dakota State University, Brookings 57007
}

\begin{abstract}
The objective of this study was to compare the effects of vacuum-condensed (CM) and ultrafiltered (UF) milk on some compositional and functional properties of Cheddar cheese. Five treatments were designed to have 2 levels of concentration (4.5 and 6.0\% protein) from vacuum-condensed milk (CM1 and CM2) and ultrafiltered milk (UF1 and UF2) along with a $3.2 \%$ protein control. The samples were analyzed for fat, protein, ash, calcium, and salt contents at $1 \mathrm{wk}$. Moisture content, soluble protein, meltability, sodium dodecyl sulfatePAGE, and counts of lactic acid bacteria and nonstarter lactic acid bacteria were performed on samples at 1 , 18 , and $30 \mathrm{wk}$. At $1 \mathrm{wk}$, the moisture content ranged from 39.2 (control) to $36.5 \%$ (UF2). Fat content ranged from 31.5 to $32.4 \%$ with no significant differences among treatments, and salt content ranged from 1.38 to $1.83 \%$ with significant differences. Calcium content was higher in UF cheeses than in CM cheeses followed by control, and it increased with protein content in cheese milk. Ultrafiltered milk produced cheese with higher protein content than CM milk. The soluble protein content of all cheeses increased during $30 \mathrm{wk}$ of ripening. Condensed milk cheeses exhibited a higher level of proteolysis than UF cheeses. Sodium dodecyl sulfate-PAGE showed retarded proteolysis with increase in level of concentration. The breakdown of $\alpha_{\mathrm{s} 1^{-}}$ casein and $\alpha_{\mathrm{s} 1}$-I-casein fractions was highest in the control and decreased with increase in protein content of cheese milk, with UF2 being the lowest. There was no significant degradation of $\beta$-casein. Overall increase in proteolytic products was the highest in control, and it
\end{abstract}

Received July 13, 2004.

Accepted August 22, 2004.

Corresponding author: V. V. Mistry; e-mail: vikram.mistry@ sdstate.edu.

*Published with the approval of director of the South Dakota Agricultural Experiment Station as Publication Number 3426 of the Journal Series. This research was sponsored, in part, by the Minnesota-South Dakota Dairy Foods Research Center, Brookings, SD, and Midwest Dairy Association, St. Paul, MN.

$\dagger$ Current address: Well's Dairy, 1 1st Street S. W., Le Mars, IA 51031. decreased with increase in protein content of cheese milk. No significant differences in the counts of lactic starters or nonstarter lactic acid bacteria were observed. Extent as well as method of concentration influenced the melting characteristics of the cheeses. Melting was greatest in the control cheeses and least in cheese made from condensed milk and decreased with increasing level of milk protein concentration. Vacuum condensing and ultrafiltration resulted in Cheddar cheeses of distinctly different quality. Although both methods have their advantages and disadvantages, the selection of the right method would depend upon the objective of the manufacturer and intended use of the cheese.

(Key words: ultrafiltration, condensing, Cheddar cheese)

Abbreviation key: $\mathbf{C M}=$ condensed milk, $\mathbf{C M 1}=$ condensed milk cheese with $4.5 \%$ protein, $\mathbf{C M 2}=$ condensed milk cheese with $6.0 \%$ protein, $\mathbf{L A B}=$ lactic acid bacteria, NSLAB = nonstarter lactic acid bacteria, UF1 = ultrafiltered milk cheese with $4.5 \%$ protein, UF2 $=$ ultrafiltered milk cheese with $6.0 \%$ protein.

\section{INTRODUCTION}

The benefits of concentration of milk before cheese making have been well documented. Concentration techniques applied to cheese making include ultrafiltration, vacuum condensing, reverse osmosis, and microfiltration. Ultrafiltration and vacuum condensing are the most common techniques, and both are in commercial use (Kosikowski and Mistry, 1997a). Ultrafiltration selectively concentrates milk proteins, fat, and colloidal salts, whereas vacuum condensing concentrates all milk solids, removing only water. Therefore, the relative proportion of protein in DM is higher in UF milk. As a result, these concentration techniques produce milks of distinctly different characteristics that also influence the manufacture of cheese from such milks. It was demonstrated in previous studies that proteolysis was retarded during the ripening of low fat cheese manufactured with milk concentrated by vacuum condensing (Anderson et al., 1993; Brandsma et 
al., 1994). Similar effects have been reported with UF (Green et al., 1981; Kealey and Kosikowski, 1985; Lelievre and Lawrence, 1988) and vacuum-condensed milk (CM) (Bemis, 1984) in various cheeses due to the presence of whey proteins. Such ripening characteristics, which also affect flavor development in cheese, would be of interest in process cheese making because it would provide greater flexibility in the selection of base cheese. Although the effects of these and other differences on cheese making have been studied independently, direct comparisons between the 2 methods with similar composition characteristics have not. The objective of this study was to compare the effects of use of vacuum-condensed and UF milk on the composition and some functional properties of Cheddar cheese.

\section{MATERIALS AND METHODS}

\section{Milk Processing}

Raw whole milk was separated (340 ATP, De Laval Separator Co., New York, NY) to cream (30 to 35\% fat) and reduced fat milk ( 0.4 to $0.6 \%$ fat). Cream was pasteurized at $65^{\circ} \mathrm{C}$ for $30 \mathrm{~min}$ in a vat (The Creamery Package Mfg. Co., Chicago, IL), cooled to less than $15^{\circ} \mathrm{C}$, and stored at 4 to $5^{\circ} \mathrm{C}$ until used. Reduced fat milk was pasteurized at $63^{\circ} \mathrm{C}$ for $30 \mathrm{~min}$ in a vat (P-300-8646, The Creamery Package Mfg. Co.), cooled to 4 to $5^{\circ} \mathrm{C}$, and split in 3 parts. The first part (175 kg) was vacuum condensed at $55^{\circ} \mathrm{C}$ in a single-stage rising film BlawKnox evaporator (C. E. Rogers, Mora, MN) to 11 to $12 \%$ protein (CM). Vacuum was maintained at $635 \mathrm{mmHg}$ and steam jacket temperature was 74 to $79^{\circ} \mathrm{C}$. The second part $(175 \mathrm{~kg})$ was ultrafiltered at $55^{\circ} \mathrm{C}$ using a spiral wound membrane (model 1/1; Koch Membrane Systems Inc., Wilmington, MA) to 15 to $16 \%$ protein (UF). The third part was blended with pasteurized cream and $\mathrm{CM}$ or UF milk to a casein:fat ratio of 0.7 and protein of $4.5 \%$ (UF1 and CM1) and $6.0 \%$ (UF2 and CM2). No concentrate was added to the control (3.2\% protein). Total quantity of blended milk was 100 to $105 \mathrm{~kg}$ for control, $72.5 \mathrm{~kg}$ for UF1 and CM1, and $54.5 \mathrm{~kg}$ for UF2 and CM2. The scheme is summarized in Figure 1.

\section{Cheddar Cheese Making}

Cheddar cheese was manufactured from the above 5 standardized milks (control, UF1, UF2, CM1, and CM2) using the method described by Kosikowski and Mistry (1997b). Cheese was manufactured from 2 randomly selected treatments each on $\mathrm{d} 1$ and 2 , and the remaining treatment was manufactured on $\mathrm{d} 3$. The temperature of the standardized milk was adjusted to 30 to $31^{\circ} \mathrm{C}$ in cheese vats (4 MX model 65, Kusel Equip- ment Co., Watertown, WI). The milks were inoculated with frozen concentrated Direct Vat Inoculation culture (Super Start M61, Rhodia Inc., Madison, WI) at $7 \mathrm{~g} / \mathrm{kg}$ of protein in cheese milk. After $30 \mathrm{~min}$ of ripening, single strength rennet (Chymostar Classic M9017, Rhodia Inc., Madison, WI) was added at $9 \mathrm{~mL} / 45.4 \mathrm{~kg}$ of milk to the control and $6 \mathrm{~mL} / 45.4 \mathrm{~kg}$ of milk to UF1, UF2, CM1, and CM2. Rennet curd was cut upon reaching optimum firmness in 25 to 35 min using $0.95-\mathrm{cm}$ (3/8-inch) wire knives in circular motion. Cooking was conducted by raising the curd temperature to $37^{\circ} \mathrm{C}$ in $30 \mathrm{~min}$ and holding for an additional $30 \mathrm{~min}$. During initial trials it was observed that cheeses manufactured from UF2 had considerably lower moisture than other treatments, hence the cooking temperature for UF2 was lowered to $36^{\circ} \mathrm{C}$ for all replications. The whey was drained at the end of cooking and curd was cheddared to a $\mathrm{pH}$ of 5.20 to 5.25 , milled and salted with dry, foodgrade salt at $2.7 \%$ by weight. The salted curd was then hooped and pressed overnight at $2.8 \mathrm{~kg} / \mathrm{cm}^{2}$ (AFVSSpec, Kusel Equipment Co., Watertown, WI). The pressed cheese block was weighed, vacuum packed, and stored at $4^{\circ} \mathrm{C}$ for ripening until used.

\section{Composition Analysis}

Samples of milk, whey, and cheese at 1 wk of age were collected and analyzed for chemical composition. Total solids in milk and whey were determined by the Mojonnier method (Atherton and Newlander, 1977). Moisture content of cheese was analyzed using Ohaus MB200 moisture balance (Ohaus Corp., Florham Park, NJ; Crosser and Mistry, 1991). Total N in milks, cream, and cheese was determined by the Kjeldahl method (991.20, AOAC, 2000). Protein was calculated by multiplying total $\mathrm{N}$ by a factor of 6.38 . Protein in fat-reduced milk, UF, and CM was estimated using an infrared instrument (Milkoscan, FOSS North America Inc., Eden Prairie, MN). Casein content of milk was assumed to be $75 \%$ of total milk protein content. Fat content was determined by the Mojonnier method (995.19; AOAC, 2000 ) and ash content by heating a 0.5 -g sample in an oven at $100^{\circ} \mathrm{C}$ for 3 to $4 \mathrm{~h}$, followed by heating at $200^{\circ} \mathrm{C}$ for $2 \mathrm{~h}$ and drying at $550^{\circ} \mathrm{C}$ overnight in a muffle furnace (935.42; AOAC, 2000). Cheese samples were analyzed for calcium and salt contents using the atomic absorption method (990.23; AOAC, 2000) (model 500, PerkinElmer Analytical Instruments, Oak Brook, IL). Cheese $\mathrm{pH}$ was measured at 1,18 , and 30 wk using a Corning pH meter (model 320, Corning Inc., Corning, NY).

\section{Proteolysis}

Proteolysis in cheese during ripening was measured at 1,18 , and 30 wk using soluble protein content (Kosi- 


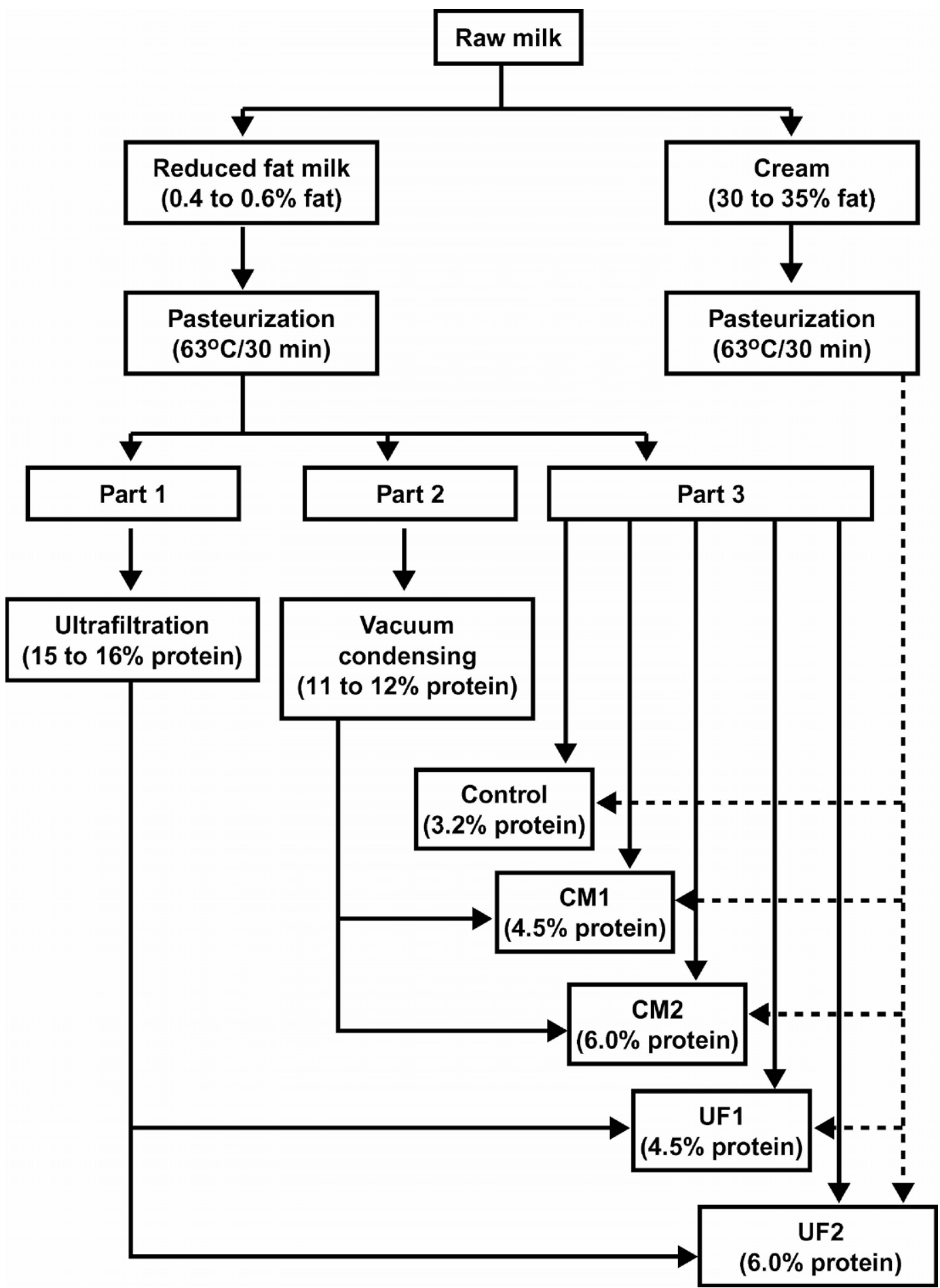

Figure 1. Scheme for milk processing and formulation of treatments.

kowski and Mistry, 1997b) and SDS-PAGE (Basch et al., 1989; Brandsma et al., 1994). For electrophoresis, grated cheese $(10 \mathrm{~g})$ was blended in a Waring blender at medium speed with $25 \mathrm{~mL}$ of protein solvent $(0.166$
$M$ Tris, $1 \mathrm{~m} M$ EDTA, $\mathrm{pH}$ 8.0) to a homogeneous slurry. Five milliliters of 7\% SDS and $2 \mathrm{~mL}$ of $10 \mathrm{~m} M$ dithiothreitol were added and stirred on a stirplate for 15 min. The mixture was centrifuged at $40,000 \times g$ at $5^{\circ} \mathrm{C}$ 
for $1 \mathrm{~h}$ (Sorvall RC-5B Refrigerated Superspeed Centrifuge, DuPont Instruments, Wilmington, DE). The lipid plug was carefully pulled aside, avoiding resuspension, and the supernatant (containing the protein) was collected in a test tube using a Pasteur pipette. A pinch $(\leq 0.01 \mathrm{~g})$ of bromophenol blue was added. The protein extract was stored at $-10^{\circ} \mathrm{C}$ until needed. Electrophoresis gels were prepared and run using a Bio-Rad Protean II Slab Cell (Bio-Rad, Richmond, CA). The separating gel was a 10 to $20 \%$ gradient acrylamide gel that was allowed to polymerize for 45 min before the stacking gel (4\%) was poured. The gel thickness was $1.5 \mathrm{~mm}$. Running buffer $(0.3 \%$ Tris, $1.44 \%$ glycine, and $0.1 \%$ SDS) and gels were maintained at $13^{\circ} \mathrm{C}$ with a constant current of $20 \mathrm{~mA}$ per stacking gel and $30 \mathrm{~mA}$ per separating gel (Bio-Rad 3000 Xi Power Supply). Total running time was 3 to $4 \mathrm{~h}$. Stacking gels were detached and discarded and the separating gels were stained overnight in a solution containing $40 \%$ ethanol, $10 \%$ glacial acetic acid, and $0.1 \%$ Coomassie blue. Gels were then destained for 6 to $8 \mathrm{~h}$ with destaining solution (40\% methanol and 10\% glacial acetic acid), photographed, and scanned with a Bio-Rad model 620 video densitometer, and analyzed using 1-D Analyst software (Bio-Rad). Protein peaks were identified and percentages of casein fractions and breakdown products were calculated (Basch et al., 1989).

\section{Microbiological Analysis}

Cheese samples obtained at all 3 ripening periods were analyzed for counts of lactic acid bacteria (LAB) using Lactobacillus MRS agar (Becton Dickinson, Sparks, MD) and nonstarter lactic acid bacteria (NSLAB) using LBS agar (Becton Dickinson). An 11-g sample of cheese was obtained aseptically and homogenized with $99 \mathrm{~mL}$ of $2 \%$ sodium citrate buffer using a stomacher. Serial dilutions were prepared in the same buffer and samples were inoculated into sterile disposable Petri plates and pour-plated with respective media. The plates were incubated anaerobically (Gas Pak Anaerobic System, BBL, Cockeysville, MD) at $32^{\circ} \mathrm{C}$ for $48 \mathrm{~h}$ for LAB and 3 to $5 \mathrm{~d}$ for NSLAB counts.

\section{Meltability}

The cheese samples were analyzed for meltability using the Schreiber test (Kosikowski and Mistry, $1997 \mathrm{~b})$ at 18 and $30 \mathrm{wk}$. Cheese discs (39 mm diameter and $5 \mathrm{~mm}$ thickness) were placed in the center of glass Petri dishes and heated in a hot air oven at $232^{\circ} \mathrm{C}$ for $5 \mathrm{~min}$. The diameter of the melted cheese circles was measured after cooling for $30 \mathrm{~min}$. Average values of 5 readings of diameter (in millimeters) at different places on the melted circles were recorded.
Table 1. Composition of cheese milk. ${ }^{1}$

\begin{tabular}{lcrrrrr}
\hline & \multicolumn{5}{c}{ Treatment $^{2}$} \\
\cline { 2 - 5 } Parameter & $\mathrm{C}$ & UF1 & UF2 & CM1 & CM2 & SEM \\
\hline Total solids, \% & $12.0^{\mathrm{d}}$ & $14.8^{\mathrm{c}}$ & $17.5^{\mathrm{b}}$ & $17.3^{\mathrm{b}}$ & $21.9^{\mathrm{a}}$ & 0.21 \\
Protein, \% & $3.2^{\mathrm{c}}$ & $4.5^{\mathrm{b}}$ & $6.0^{\mathrm{a}}$ & $4.5^{\mathrm{b}}$ & $6.0^{\mathrm{a}}$ & 0.05 \\
Fat, \% & $3.4^{\mathrm{c}}$ & $4.8^{\mathrm{b}}$ & $6.4^{\mathrm{a}}$ & $4.8^{\mathrm{b}}$ & $6.4^{\mathrm{a}}$ & 0.05 \\
Ash, \% & $0.70^{\mathrm{e}}$ & $0.76^{\mathrm{d}}$ & $0.86^{\mathrm{c}}$ & $0.95^{\mathrm{b}}$ & $1.17^{\mathrm{a}}$ & 0.05 \\
Calcium, \% & $0.11^{\mathrm{d}}$ & $0.15^{\mathrm{c}}$ & $0.19^{\mathrm{b}}$ & $0.16^{\mathrm{c}}$ & $0.21^{\mathrm{a}}$ & 0.01 \\
pH & $6.7^{\mathrm{a}}$ & $6.7^{\mathrm{a}}$ & $6.7^{\mathrm{a}}$ & $6.6^{\mathrm{a}}$ & $6.5^{\mathrm{b}}$ & 0.06 \\
\hline
\end{tabular}

a,b,c,d,e Means in the same row without common superscripts are significantly $(P \leq 0.05)$ different. Means with no superscripts do not have significant interaction between method and level of concentration.

${ }^{1}$ Mean of 6 replicates.

${ }^{2}$ Treatment: $\mathrm{C}=$ Control; $\mathrm{UF} 1=4.5 \%$ protein ultrafiltered milk; $\mathrm{UF} 2=6.0 \%$ protein ultrafiltered milk; $\mathrm{CM} 1=4.5 \%$ protein condensed milk; CM2 $=6.0 \%$ protein condensed milk.

\section{Statistical Analyses}

Data were analyzed using factorial randomized block design with method (control, UF, and CM) and level of concentration $(3.2,4.5$, and $6.0 \%$ protein) as factors, and using repeated measures design with ripening time $(1,18$, and $30 \mathrm{wk})$ as a factor. Means were compared using Fisher's Least Significant Difference (LSD) procedure. The GLM procedure in SAS (SAS Institute, 1990) was used to analyze the data. A 95\% level of significance was used for all analyses. The entire experiment was replicated 6 times, that is, for each of 6 replicates of cheese making, milk was separately processed 6 times.

\section{RESULTS AND DISCUSSION}

\section{Composition of Milk}

The mean protein contents of the cheese milks were 3.2 (control), 4.5 (UF1, CM1), and 6.0\% (UF2, CM2), and the casein-to-fat ratios were 0.7 (Table 1). The total solids content ranged from 12.0 (control) to $21.9 \%$ (CM2). Ash and calcium contents were also significantly $(P \leq 0.05)$ different among the treatments because of the extent and method of concentration. As expected, the control had the lowest ash and calcium content, followed by UF milks, and CM milks had the highest contents. The $\mathrm{pH}$ of milk for all treatments were similar except for CM2, which was lower $(P \leq 0.05)$.

\section{Composition of Whey}

The percentage of all constituents in whey increased with increase in concentration from control to 4.5 (UF1, CM1) to $6.0 \%$ (UF2, CM2) (Table 2). The concentration of all components in whey from CM was higher than in the corresponding UF whey. 
Table 2. Composition of cheese whey obtained at draining. ${ }^{1}$

\begin{tabular}{lllllll}
\hline & \multicolumn{5}{c}{ Treatment $^{2}$} \\
\cline { 2 - 6 } Parameter & C & UF1 & UF2 & CM1 & CM2 & SEM \\
\hline Total solids, \% & $6.2^{\mathrm{e}}$ & $6.6^{\mathrm{d}}$ & $7.0^{\mathrm{c}}$ & $9.5^{\mathrm{b}}$ & $11.4^{\mathrm{a}}$ & 0.25 \\
Protein, \% & 0.92 & 1.25 & 1.70 & 1.33 & 1.86 & 0.05 \\
Fat, \% & 0.36 & 0.41 & 0.65 & 0.42 & 0.71 & 0.04 \\
Ash, \% & $0.46^{\mathrm{e}}$ & $0.60^{\mathrm{c}}$ & $0.52^{\mathrm{d}}$ & $0.78^{\mathrm{b}}$ & $0.91^{\mathrm{a}}$ & 0.03 \\
pH & 6.3 & 6.3 & 6.2 & 6.2 & 6.0 & 0.13 \\
\hline
\end{tabular}

a,b,c,d,e Means in the same row without common superscripts are significantly $(P \leq 0.05)$ different. Means with no superscripts do not have significant interaction between method and level of concentration.

${ }^{1}$ Mean of 6 replicates.

${ }^{2}$ Treatment: $\mathrm{C}=$ Control; UF1 $=4.5 \%$ protein ultrafiltered milk; $\mathrm{UF} 2=6.0 \%$ protein ultrafiltered milk; $\mathrm{CM} 1=4.5 \%$ protein condensed milk; $\mathrm{CM} 2=6.0 \%$ protein condensed milk.

\section{Composition of Cheese}

The effects of method and level of concentration on moisture content of cheese were significant $(P \leq 0.05)$, but the interaction was not significant (Table 3). As the level of concentration increased (control vs. UF1 vs. UF2, and control vs. CM1 vs. CM2), moisture content decreased. Similar effects have been reported by Green et al. (1981) and Kosikowski et al. (1985) in Cheddar cheese manufactured with the use of UF milk. Fat content in cheese ranged from 31.5 to $32.4 \%$, and protein content from 24.7 to $26.4 \%$. Protein content in cheese increased as the level of concentration of cheese milk increased. Kosikowski et al. (1985) reported similar effects in Cheddar cheese made from whole milk supplemented with UF milk. Jensen et al. (1987) discussed similar reports in their review of cheese composition

Table 3. Composition of Cheddar cheese at $1 \mathrm{wk}$ of age. ${ }^{1}$

\begin{tabular}{llccccc}
\hline & \multicolumn{5}{c}{ Treatment $^{2}$} \\
\cline { 2 - 6 } Parameter & C & UF1 & UF2 & CM1 & CM2 & SEM \\
\hline Moisture, \% & 39.2 & 37.8 & 36.5 & 38.6 & 36.7 & 0.75 \\
MNFS, \% $\%$ & 57.7 & 55.6 & 54.0 & 56.3 & 53.6 & 0.93 \\
Protein, \% & 24.9 & 25.6 & 26.4 & 24.7 & 25.4 & 0.47 \\
Fat, \% & 32.1 & 32.1 & 32.4 & 31.6 & 31.5 & 0.61 \\
Salt, \% & $1.4^{\mathrm{b}}$ & $1.4^{\mathrm{b}}$ & $1.4^{\mathrm{b}}$ & $1.5^{\mathrm{b}}$ & $1.8^{\mathrm{a}}$ & 0.17 \\
S/M, \% & $3.5^{\mathrm{b}}$ & $3.8^{\mathrm{b}}$ & $3.8^{\mathrm{b}}$ & $3.9^{\mathrm{b}}$ & $5.0^{\mathrm{a}}$ & 0.49 \\
Ash, \% & 2.8 & 3.1 & 3.4 & 3.2 & 3.6 & 0.18 \\
Calcium, \% & 0.68 & 0.75 & 0.80 & 0.71 & 0.77 & 0.05 \\
pH & 5.1 & 5.1 & 5.1 & 5.0 & 5.1 & 0.06 \\
\hline
\end{tabular}

${ }^{\mathrm{a}, \mathrm{b}}$ Means in the same row without common superscripts are significantly $(P \leq 0.05)$ different. Means with no superscripts do not have significant interaction between method and level of concentration.

${ }^{1}$ Mean of 6 replicates.

${ }^{2}$ Treatment: $\mathrm{C}=$ Control; UF1 $=4.5 \%$ protein ultrafiltered milk; $\mathrm{UF} 2=6.0 \%$ protein ultrafiltered milk; $\mathrm{CM} 1=4.5 \%$ protein condensed milk; $\mathrm{CM} 2=6.0 \%$ protein condensed milk

${ }^{3} \mathrm{MNFS}=$ Moisture in not-fat substances.

${ }^{4} \mathrm{~S} / \mathrm{M}=$ Salt in moisture. made from UF milk. There were significant $(P \leq 0.05)$ differences between calcium and ash content of cheeses. Although the ash content was higher in CM than in UF cheeses, calcium content was significantly $(P \leq 0.05)$ higher in UF cheeses. This could be because during vacuum condensing all the minerals are concentrated equally, whereas ultrafiltration results in a higher concentration of colloidal calcium but soluble minerals are removed. Control cheeses had the lowest amount of calcium and ash content and were as expected for cheeses manufactured from unconcentrated milk. Ultrafiltration is known to produce cheeses with higher calcium (Glover, 1985). It was interesting to note that CM2 cheeses had significantly $(P \leq 0.05)$ higher salt content compared with UF and control cheeses, indicating that vacuum condensing may increase salt retention in Cheddar cheese. This has been confirmed by Nair et al., 2004. Also, as the level of concentration increased, salt content increased.

\section{Proteolysis}

The method and level of concentration and ripening time had significant $(P \leq 0.05)$ effects on proteolysis (soluble protein and electrophoresis). Soluble protein content decreased as the level of protein concentration in cheese milk increased from $3.2 \%$ (control), to $4.5 \%$ (UF1, CM1), and 6.0\% (UF2, CM2), regardless of age of cheese (Figure 2a). At $1 \mathrm{wk}$, soluble protein for control, UF1, UF2, CM1, and CM2 was 2.58, 2.35, 2.11, 2.2 , and $1.91 \%$, respectively. After 18 wk of ripening, it increased to $4.84,3.79,3.17,3.83$, and $3.46 \%$, and at the end of 30 -wk period, the soluble proteins were 10.95, $9.87,7.49,10.45$, and $9.95 \%$, respectively. The control cheeses had the highest concentration of soluble protein at all ripening periods, and UF cheeses had significantly $(P \leq 0.05)$ lower soluble protein compared with CM cheeses after 18 and 30 wk of ripening. Bemis (1984) reported a decline in water-soluble nitrogen of cheese with vacuum condensing of both whole and skim milk in Cheddar cheese making. Brandsma et al. (1994) reported similar reduction in soluble nitrogen content of reduced fat Cheddar cheeses upon use of CM $(1.5,1.8$, and $2 \times$ ).

The peaks identified by SDS-PAGE were divided into 5 groups (Anderson et al., 1993; Brandsma et al., 1994) (Figure 3). Group I included high molecular weight noncaseins prior to $\alpha_{\mathrm{s} 1}$-casein (Table 4 ). Next were the bands of $\alpha_{\mathrm{s} 1}$-casein, $\alpha_{\mathrm{s} 1}$-I-casein, and $\beta$-casein, included under the title of caseins. All bands after $\beta$-casein and before para- $\kappa$-casein were included in group II (casein degradation products) (Basch et al., 1989). Next was the band for para- $\kappa$-casein. Group III included low molecular weight noncasein degradation products. The 

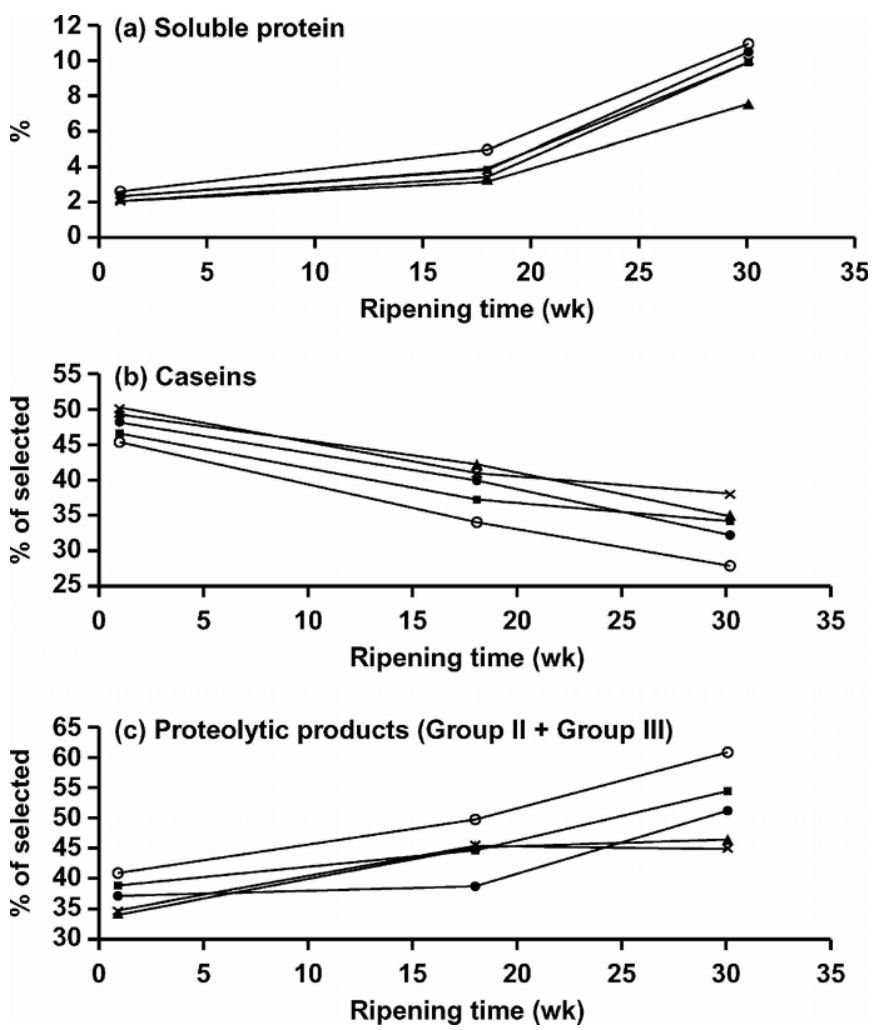

Figure 2. Proteolysis in Cheddar cheeses during ripening. $(\bigcirc)$

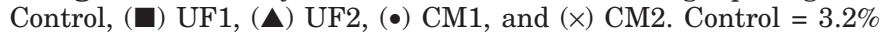
protein unconcentrated milk; UF1 $=4.5 \%$ protein ultrafiltered milk; $\mathrm{UF} 2=6.0 \%$ protein ultrafiltered milk; $\mathrm{CM} 1=4.5 \%$ protein condensed milk; $\mathrm{CM} 2=6.0 \%$ protein condensed milk.

proportions of these proteins in cheeses at $30 \mathrm{wk}$ of ripening are presented in Table 4. Proportion of high molecular weight proteins (group I) was significantly $(P \leq 0.05)$ lower in controls compared with concentrates. Proportion of caseins ( $\alpha_{\mathrm{s}}$-casein, $\alpha_{\mathrm{s} 1}$-casein, and $\beta$-casein) increased with increases in concentration $(P \leq$ 0.05 ), but was unaffected by method of concentration, indicating higher proteolysis in the control compared with concentrates. Higher level of group II and group III bands in the control compared with concentrates further confirmed the differences (Figure 2b,c). Anderson et al. (1993) reported a significant increase in remaining caseins $\left(\alpha_{\mathrm{s} 1}, \alpha_{\mathrm{s} 2}\right.$, and $\left.\beta\right)$ with increase in concentration $(1.5,1.8$, and $2 \times)$ in reduced-fat Cheddar cheese from CM. Brandsma et al. (1994) also observed an increase in remaining caseins and reduction in degradation products (group II and group III) at $12 \mathrm{wk}$ with increase in concentration of milk $(1.5,1.8$, and $2 \times)$ for reduced-fat Cheddar cheese made from CM.

Results of soluble protein and SDS-PAGE agree and indicate slower proteolysis in cheeses from concentrates compared with control, with level of concentration as governing factor.
Std. C UF1 UF2 CM1 CM2
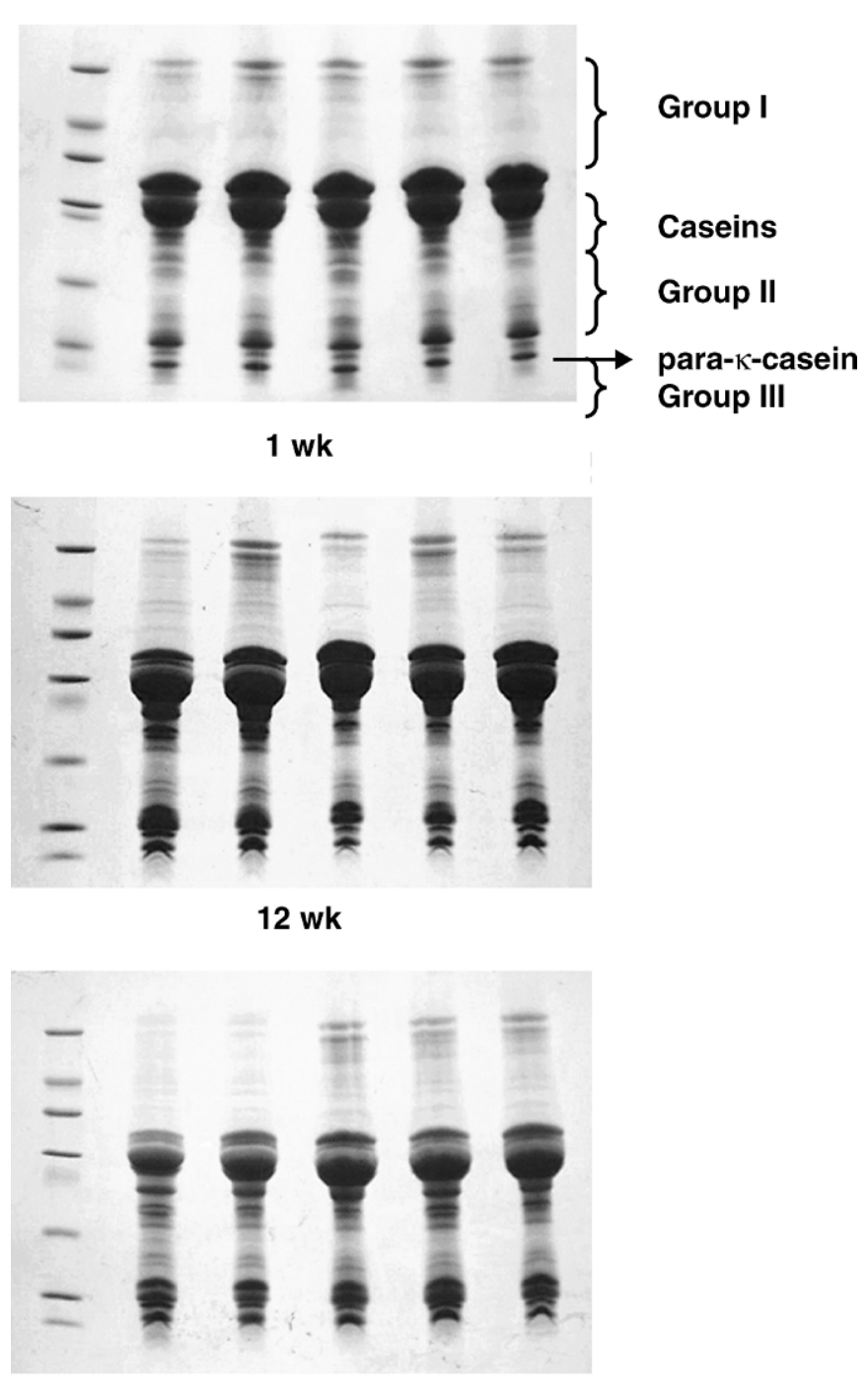

30 wk

Figure 3. Sodium dodecyl sulfate-PAGE gels of Cheddar cheese at different ripening periods. $\mathrm{C}=\mathrm{Control}$; $\mathrm{UF} 1=4.5 \%$ protein ultrafiltered milk; $\mathrm{UF} 2=6.0 \%$ protein ultrafiltered milk; $\mathrm{CM} 1=4.5 \%$ protein condensed milk; CM2 $=6.0 \%$ protein condensed milk.

\section{Meltability}

The melting characteristics of cheeses at $30 \mathrm{wk}$ are shown in Figure 4. At $18 \mathrm{wk}$, the meltability values were 70.2 (control), 66.5 (UF1), 58.8 (UF2), 56.7 (CM1), and $52.0 \mathrm{~mm}$ (CM2). At the end of $30 \mathrm{wk}$, values increased to 77.2 (control), 67.6 (UF1), 61.5 (UF2), 57.7 (CM1), and $54.1 \mathrm{~mm}$ (CM2) (Table 5). Effect of level and method of concentration were significant $(P \leq 0.05)$ at 18 and $30 \mathrm{wk}$. Meltability decreased as the level of concentration increased. Condensed milk cheeses had significantly $(P \leq 0.05)$ lower meltability values com- 
Table 4. Proportion of different groups (\%) of proteins obtained by SDS-PAGE of Cheddar cheese at $30 \mathrm{wk}$ of ripening based on densitometry. ${ }^{1}$

\begin{tabular}{lrrrrrr}
\hline & \multicolumn{5}{c}{ Treatment $^{2}$} \\
\cline { 2 - 5 } Group $^{3}$ & $\mathrm{C}$ & UF1 & UF2 & CM1 & CM2 & SEM \\
\hline Group I & $0.7^{\mathrm{b}}$ & $1.5^{\mathrm{b}}$ & $6.1^{\mathrm{a}}$ & $4.6^{\mathrm{a}}$ & $6.2^{\mathrm{a}}$ & 1.58 \\
Caseins & $28.2^{\mathrm{c}}$ & $34.5^{\mathrm{b}}$ & $36.2^{\mathrm{ab}}$ & $33.4^{\mathrm{b}}$ & $38.5^{\mathrm{a}}$ & 3.00 \\
Group II & $41.7^{\mathrm{a}}$ & $37.1^{\mathrm{ab}}$ & $33.0^{\mathrm{bc}}$ & $36.3^{\mathrm{b}}$ & $30.1^{\mathrm{c}}$ & 3.91 \\
Para- $\kappa$-casein & $9.8^{\mathrm{a}}$ & $9.1^{\mathrm{a}}$ & $9.9^{\mathrm{a}}$ & $11.0^{\mathrm{a}}$ & $10.3^{\mathrm{a}}$ & 1.84 \\
Group III & $19.5^{\mathrm{a}}$ & $17.8^{\mathrm{b}}$ & $15.0^{\mathrm{b}}$ & $14.8^{\mathrm{b}}$ & $14.9^{\mathrm{b}}$ & 3.07 \\
\hline
\end{tabular}

a,b,c Means in the same row without common superscripts are significantly $(P \leq 0.05)$ different. Means with no superscripts do not have significant interaction between method and level of concentration.

${ }^{1}$ Mean of 6 replicates.

${ }^{2}$ Treatment: $\mathrm{C}=$ Control; $\mathrm{UF} 1=4.5 \%$ protein ultrafiltered milk; $\mathrm{UF} 2=6.0 \%$ protein ultrafiltered milk; $\mathrm{CM} 1=4.5 \%$ protein condensed milk; $\mathrm{CM} 2=6.0 \%$ protein condensed milk.

${ }^{3}$ Group I = high molecular weight noncaseins; Group II = casein degradation products; Group III = low molecular weight noncasein degradation products.

pared with UF and control cheeses. Meltability increased with increase in proteolysis. However, CM cheeses had lower meltability in spite of a higher extent of proteolysis compared with UF cheeses. Oommen et al. (2000) studied the effect of supplementation of cheese milk with UF retentate to protein contents of 4.57 and $5.93 \%$, similar to UF1 and UF2 in this study, and found a reduction in meltability of cheeses. Increase in meltability can be directly correlated with extent of proteolysis, resulting in breakdown of casein matrix, release of calcium, and increased hydration (Lawrence, 1987). It is suggested that the lowering in meltability of cheeses made from UF is due to the entrapment of free moisture by the denatured whey proteins (Sood and Kosikowski, 1979; Banks, 1990). Aizawa and Yoneda (1990) suggested that lower moisture content, lower
Table 5. Meltability (mm) of Cheddar cheese at 18 and 30 wk of ripening. ${ }^{1}$

\begin{tabular}{lllllll}
\hline & \multicolumn{5}{c}{ Treatment $^{2}$} \\
\cline { 2 - 5 } Ripening time & $\mathrm{C}$ & UF1 & UF2 & CM1 & CM2 & SEM \\
\hline 18 wk & $70.2^{\mathrm{a}}$ & $66.5^{\mathrm{b}}$ & $58.8^{\mathrm{c}}$ & $56.7^{\mathrm{c}}$ & $52.0^{\mathrm{d}}$ & 2.8 \\
$30 \mathrm{wk}$ & $77.2^{\mathrm{a}}$ & $67.6^{\mathrm{b}}$ & $61.5^{\mathrm{c}}$ & $57.7^{\mathrm{cd}}$ & $54.1^{\mathrm{d}}$ & 4.8 \\
\hline a,b,c,d Means in the same row without common superscripts are sig- \\
nificantly ( $P \leq 0.05)$ different. Means with no superscripts do not have \\
significant interaction between method and level of concentration. \\
${ }^{1}$ Mean of 6 replicates. \\
${ }^{2}$ Treatment: C = Control; UF1 = 4.5\% protein ultrafiltered milk; \\
UF2 = 6.0\% protein ultrafiltered milk; CM1 = 4.5\% protein condensed \\
milk; CM2 = 6.0\% protein condensed milk.
\end{tabular}

fat-to-protein ratio, and higher calcium content could lead to a decline in meltability of process cheese. Both UF and CM cheeses had higher calcium and lower moisture content and lower fat-to-protein ratio $(1.28,1.23$, 1.28, and 1.24 for UF1, UF2, CM1, and CM2, respectively) compared with the control (1.29), partly explaining the lower meltability values. Condensed milk cheeses had lower meltability than UF cheeses despite higher moisture content, higher extent of proteolysis, higher fat-to-protein ratio, and lower calcium content. A probable reason for lower meltability of CM cheeses could be an increase in the concentration of colloidal calcium during condensing because of a shift in equilibrium between colloidal and ionic calcium as the concentration of soluble calcium increases with removal of water. Holding milk at higher temperatures (45 to $50^{\circ} \mathrm{C}$ ) during condensing for an extended period of time could be another factor contributing to lower meltability of cheeses. Further experiments to reduce the colloidal calcium level in cheese milk, such as diafiltration, addition of sodium chloride, or acidification, may be helpful in determining the relationship between colloidal cal-

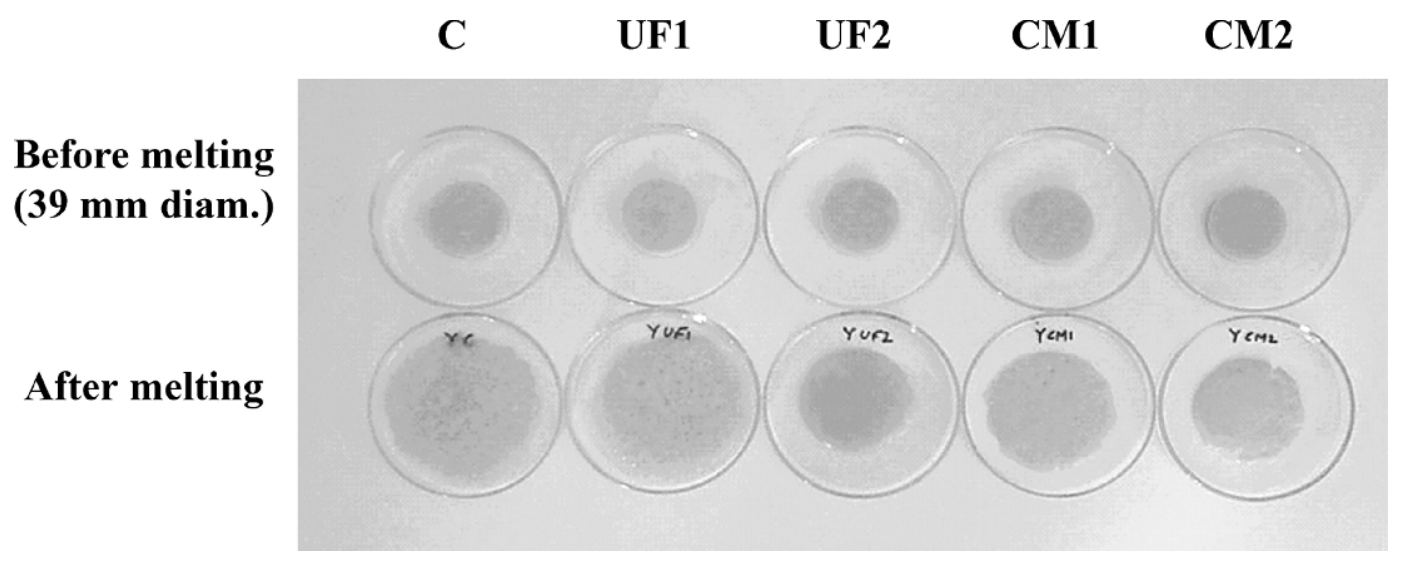

Figure 4. Meltability of Cheddar cheeses by Schreiber test at $30 \mathrm{wk}$ of ripening. $\mathrm{C}=$ Control; UF1 $=4.5 \%$ protein ultrafiltered milk; $\mathrm{UF} 2=6.0 \%$ protein ultrafiltered milk; $\mathrm{CM} 1=4.5 \%$ protein condensed milk; CM $2=6.0 \%$ protein condensed milk. 


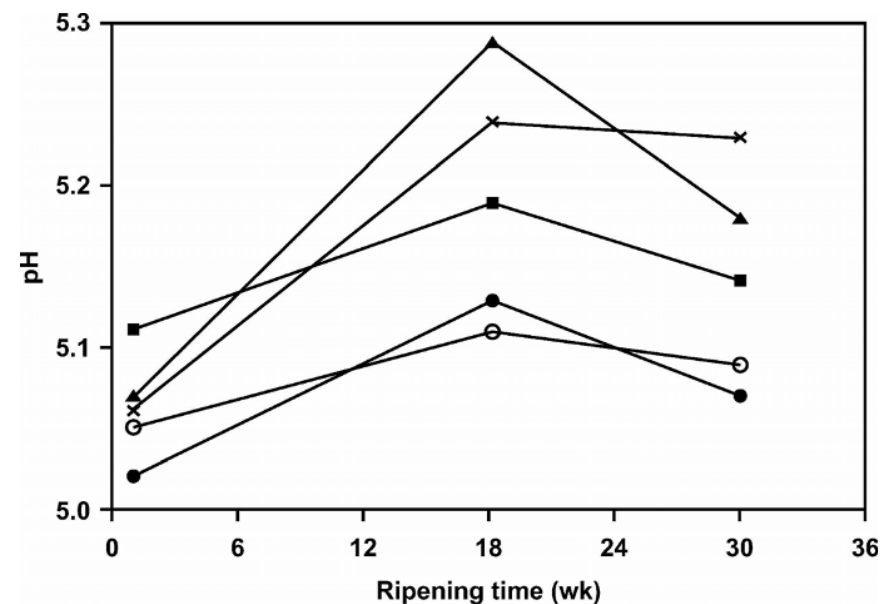

Figure 5. Changes in $\mathrm{pH}$ of Cheddar cheese during ripening. $(\mathrm{O})$

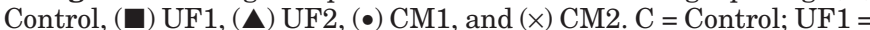
$4.5 \%$ protein ultrafiltered milk; $\mathrm{UF} 2=6.0 \%$ protein ultrafiltered milk; $\mathrm{CM} 1=4.5 \%$ protein condensed milk; $\mathrm{CM} 2=6.0 \%$ protein condensed milk.

cium content and meltability and possibly explain lower meltability of CM cheeses.

\section{$\mathrm{pH}$}

During cheese ripening, NSLAB continue to produce acids and alkaline proteolytic products. $\mathrm{pH}$ can be a measure to observe the shifts in the balance between proteolysis and acid production. During the first week or two, starter bacteria ferment the residual lactose and reduce $\mathrm{pH}$ (Choisy et al., 2000). Thereafter, the activity of NSLAB results in an increase in $\mathrm{pH}$, as in this study (Figure 5). After that, $\mathrm{pH}$ remains almost the same or declines a little, probably due to accumulation of acids. At all ripening periods, control and CM1 cheeses had significantly $(P \leq 0.05)$ lower $\mathrm{pH}$ values than the rest of the treatments. This corresponds with the higher moisture and greater extent of proteolysis of these treatments.

\section{Microbial Counts}

Counts of starter bacteria and NSLAB are an indication of the normal course of ripening. Major shifts in populations of these groups can have significant effects on extent of proteolysis and, hence, sensory attributes as well as meltability. The levels of these groups are influenced by composition of cheese as it ripens (Kosikowski and Mistry, 1997a; Fox et al., 2000). Figure 6 shows changes in populations of both groups of bacteria. There were no significant $(P \geq 0.05)$ differences in counts among treatments at any ripening period, but ripening time was the only factor that had a significant
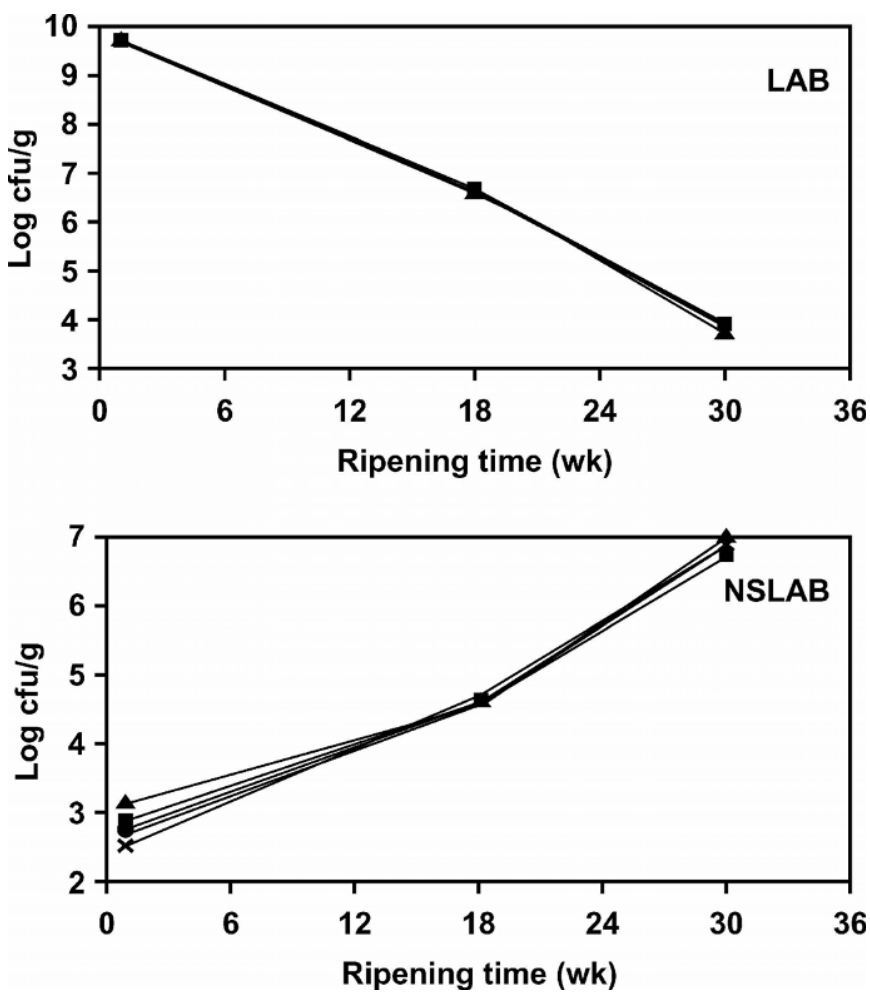

Figure 6. Changes in counts of lactic acid bacteria (LAB) and nonstarter lactic acid bacteria (NSLAB) in Cheddar cheese during

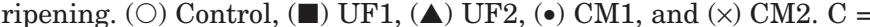
Control; UF $1=4.5 \%$ protein ultrafiltered milk; UF2 $=6.0 \%$ protein ultrafiltered milk; $\mathrm{CM} 1=4.5 \%$ protein condensed milk; $\mathrm{CM} 2=6.0 \%$ protein condensed milk.

$(P \leq 0.05)$ influence. Counts of starter bacteria were the highest (9 to $10 \mathrm{log} \mathrm{cfu} / \mathrm{g}$ ) at $1 \mathrm{wk}$ and dropped to 6 to $7 \mathrm{log} \mathrm{cfu} / \mathrm{g}$ at $18 \mathrm{wk}$, and 3 to $4 \mathrm{log} \mathrm{cfu} / \mathrm{g}$ at $30 \mathrm{wk}$ of ripening. Nonstarter LAB counts were lowest at $1 \mathrm{wk}$ (2 to $3 \mathrm{log} \mathrm{cfu} / \mathrm{g}$ ) and increased to 4 to $5 \mathrm{log} \mathrm{cfu} / \mathrm{g}$ at 18 wk, and 6 to $7 \mathrm{log} \mathrm{cfu} / \mathrm{g}$ at $30 \mathrm{wk}$ of ripening. These results were close to reported NSLAB counts of 1 to 2 $\log \mathrm{cfu} / \mathrm{g}$ at $1 \mathrm{~d}$ (Walsh et al., 1996), 2 to $3 \mathrm{log} \mathrm{cfu} / \mathrm{g}$ at 2 wk (Swearingen et al., 2001), 5 to $7 \mathrm{log} \mathrm{cfu} / \mathrm{g}$ at 12 wk (Swearingen et al., 2001), and $8 \mathrm{log} \mathrm{cfu} / \mathrm{g}$ at $24 \mathrm{wk}$ (Walsh et al., 1996).

\section{CONCLUSIONS}

It is concluded from the present study that concentration of cheese milk by ultrafiltration or vacuum condensing produces Cheddar cheeses with lower moisture, higher protein, higher calcium, slower proteolysis, and decreased meltability. Ultrafiltration produces cheeses with lower moisture, higher protein, lower ash, higher calcium, lower proteolysis, and higher meltability when compared with vacuum-condensed milk. Thus, although both methods have their advantages and dis- 
advantages, the selection of the right method would depend upon the objective of the manufacturer and intended use of the cheese.

\section{REFERENCES}

Aizawa, S., and Y. Yoneda. 1990. Preparation of melt-resistant Process cheese. Page 537 in Brief Comm. XXIII Int. Dairy Congr., Montreal, October 8-12. Vol. II. International Dairy Federation, Brussels, Belgium.

Anderson, D. L., V. V. Mistry, R. L. Brandsma, and K. A. Baldwin. 1993. Reduced fat Cheddar cheese from condensed milk. 1. Manufacture, composition, and ripening. J. Dairy Sci. 76:2832-2844.

Association of Official Analytical Chemists. 2000. Official Methods of Analysis, 17th ed.. AOAC, Gaithersburg, MD.

Atherton, H. V., and J. A. Newlander. 1977. Chemistry and Testing of Dairy Products. AVI Publ. Co., Inc., Westport, CT.

Banks, J. M. 1990. Improving cheese yield by the incorporation of whey powder. Dairy Ind. Int. 55:37.

Basch, J. J., H. M. J. Farrell, R. A. Walsh, R. P. Konstance, and T. F. Kumosinski. 1989. Development of a quantitative model for enzyme-catalyzed, time-dependent changes in protein composition of Cheddar cheese during storage. J. Dairy Sci. 72:591-603.

Bemis, C. A. 1984. The manufacture of Cheddar cheese using vacuum concentrated milks. M.S. Thesis, South Dakota State University, Brookings.

Brandsma, R. L., V. V. Mistry, D. L. Anderson, and K. A. Baldwin. 1994. Reduced fat Cheddar cheese from condensed milk. 3. Accelerated ripening. J. Dairy Sci. 77:897-906.

Choisy, C., M. Desmazeaud, J. C. Gripon, G. Lambert, and J. Lenoir. 2000. The biochemistry of ripening. Pages $82-154$ in Cheesemaking: From Science to Quality Assurance. A. Eck and J. C. Gillis, ed. Lavoisier Publishing, Paris, France.

Crosser, A. E., and V. V. Mistry. 1991. Use of a moisture balance to determine moisture in cheese. J. Dairy Sci. 74(Suppl.1):126. (Abstr.)

Fox, P. F., T. P. Guinee, T. M. Cogan, and P. L. H. McSweeney. 2000. Fundamentals of Cheese Science. Aspen Publishers, Inc., Gaithersburg, MD.
Glover, F. A. 1985. Ultrafiltration and Reverse Osmosis for the Dairy Industry. National Institute for Research in Dairying, Reading, UK.

Green, M. L., F. A. Glover, E. M. W. Scurlock, R. J. Marshall, and D. A. Hatfield. 1981. The effect of use of milk concentrated by ultrafiltration on the manufacture and ripening of Cheddar cheese. J. Dairy Res. 48:333-341.

Jensen, L. A., M. E. Johnson, and N. F. Olson. 1987. Composition and properties of cheeses from milk concentrated by ultrafiltration and reverse osmosis: A review of literature. Cult. Dairy Prod. J. 22:6-14.

Kealey, K. S., and F. V. Kosikowski. 1985. Cheddar cheese from ultrafiltered whole milk retentates in industrial cheese making. J. Dairy Sci. 68:3148-3154.

Kosikowski, F. V., A. R. Masters, and V. V. Mistry. 1985. Cheddar cheese from retentate-supplemented whole milk. J. Dairy Sci. 68:548-554.

Kosikowski, F. V., and V. V. Mistry. 1997a. Cheese and Fermented Milk Foods. Vol. I. Origins and Principles. F. V. Kosikowski and Associates, Westport, CT

Kosikowski, F. V., and V. V. Mistry. 1997b. Cheese and Fermented Milk Foods. Vol. II. Procedures and Analysis. F. V. Kosikowski and Associates, Westport, CT.

Lawrence, R. C. 1987. The use of ultrafiltration technology in cheesemaking. IDF Document B 136, Int. Dairy Fed., Brussels, Belgium.

Lelievre, J., and R. C. Lawrence. 1988. Manufacture of cheese from milk concentrated by ultrafiltration. J. Dairy Res. 55:465-478.

Nair, S. S., V. V. Mistry, and K. R. Nauth. 2004. Reduction of salt $(\mathrm{NaCl})$ losses during the manufacture of Cheddar cheese. J. Dairy Sci. 87:2831-2838.

Oommen, B. S., V. V. Mistry, and M. G. Nair. 2000. Effect of homogenization of cream on composition, yield, and functionality of Cheddar cheese made from milk supplemented with ultrafiltered milk. Lait 80:77-91.

SAS User's Guide: Statistics, Version 6 Edition. 1990. SAS Inst., Inc., Cary, NC.

Sood, V. K., and F. V. Kosikowski. 1979. Process Cheddar cheese from plain and enzyme treated retentates. J. Dairy Sci. 62:1713-1718.

Swearingen, P. A., D. J. O'Sullivan, and J. J. Warthesen. 2001. Isolation, characterization, and influence of native, nonstarter lactic acid bacteria on Cheddar cheese quality. J. Dairy Sci. 84:50-59.

Walsh, E. M., P. L. H. McSweeney, and P. F. Fox. 1996. Use of antibiotics to inhibit nonstarter lactic acid bacteria in Cheddar cheese. Int. Dairy J. 6:425-431. 